\title{
On Current Situation, Defects and Countermeasures of College English Classroom Teaching Mode
}

\author{
Jing Li, Yuting Wang \\ Harbin University of Science and Technology, Harbin Heilongjiang, 150080, China
}

\begin{abstract}
Key words: College English, Classroom teaching, Current situation analysis, Countermeasures.
\end{abstract}
\begin{abstract}
English teaching as an important constituent part of college quality-oriented education in China plays a significant role in training interdisciplinary talents with application ability and competitive capacity. Classroom is the fundamental and important place for teaching activity. The key to improving college English teaching quality is classroom teaching. This paper studies and analyzes the current situation of college English classroom teaching mode and proposes corresponding countermeasures for problems and defects of current English teaching, in the hope of effectively promoting the quality of college English classroom teaching.
\end{abstract}

\section{Introduction}

As economic globalization develops and China joined WTP, English as a language which is most widely applied plays an increasingly important role in social and economic development. Hence, it receives much attention from each industry and field. Especially in educational field, English teaching occupies an increasingly important position in college teaching activity ${ }^{[1]}$. However, in English teaching for many years, teachers have accumulated valuable teaching experience, but a complete and scientific teaching mode which adapts to actual English teaching situation in China still fails to form. Thus, college English classroom teaching effect cannot reach teaching objective. Students' practical application ability and oral communication ability are poor, and they cannot adapt to social demand. Although the factors resulting in such result are extensive, the classroom as the basic place of teaching activity is a main approach for students to learn English. Thus, improving teaching quality of college English and creating suitable classroom teaching mode can effectively promote college English teaching quality. This paper puts forward corresponding countermeasures for actual teaching situation of English classroom, in the hope of reaching the teaching objective.

\section{Current situation of college classroom teaching mode}

In current college English classroom teaching, teachers cannot teach students according to their personalized development due to the influence of traditional teaching mode. Teachers' communication with students is insufficient, and they cannot implement the new requirement interaction with students. Meanwhile, since colleges has increased enrollment continuously in recent years, the teacher-student ratio is unbalanced. The teaching resources are insufficient to meet teaching requirements. Besides, teachers also need to improve their professional quality so as to adapt to English classroom teaching requirements. Students fail to well interact and communicate with teachers and their interest in English learning is insufficient. They are forced to learn English. Teachers fail to well guide students ${ }^{[2]}$. In addition, students gradually realize the importance of independent study and effort, but their learning effect is not good enough, because they fail to form favorable independent study habits in long-term study. Thus, teachers can neither teach students in 
accordance of their aptitude nor attach importance to personalized development in the process of college English classroom teaching. Students fail to form the habit of active learning.

\section{Analysis of defects of college English classroom teaching}

College English classroom teaching has been implemented for many years in Chinese colleges. Teaching quality and students' English level have made great progress. But, as colleges increase enrollment continuously and the number of students increases constantly, colleges cannot adapt to current teaching requirements in terms of teaching facilities and teaching resources. This to some extent influences classroom teaching quality. Thus, some defects exist in current college English classroom teaching on the whole. The detailed problems are as follows:

\section{Teaching idea is old-fashioned}

For a long time, the idea of exam-oriented education has run through the whole education and teaching stage. From middle school to college, English teaching evaluation is based on scores, and examination contents serve as the teaching contents. Students' learning methods are dominated by test-taking skills. Teachers focus on the pass percent of scores, while colleges pay attention to CET-4 certificate. Under such idea, the phenomena of high score, low ability, valuing scores and ignoring ability appear ${ }^{[3]}$.

\section{Value learning of basic knowledge and ignore cultivation of language communication ability}

Due to the long-term influence of traditional teaching mode, basic knowledge cultivation has been taken as the key point of teaching activity in college English classroom teaching, and students' language application ability and communication ability are ignored. Thus, dumb English appears in English teaching. Students almost have no ability to communicate with others. They even need to understand some English films with the help of Chinese captions. English as an applied discipline stresses practical application and communication ability. The ultimate purpose of language teaching is to train people's communication ability. Such ability is needed by current society. Only those learning communication ability can master ore knowledge in language learning. Those mastering grammar and vocabulary may not apply the language. Thus, students should be required to apply actual situation to communicate and use English as far as possible in English classroom teaching. Teachers should guide students to actively apply English. In college English classroom teaching, teachers should implement teaching activity according to language rules, lay emphasis on cultivating students' knowledge and skill application, guide them to overall apply the knowledge in teaching practice and improve students' language application ability in an all-round way. Thus, the shortcoming of current college English classroom teaching is that teachers only pay attention to cultivating students' grammar and vocabulary ability, but ignore cultivation of practical application ability.

\section{Teachers' professional quality remains improving and the level of teaching staff needs improving}

a). As colleges continuously increase enrollment and student scale further expands, the growth rate of teaching staff cannot adapt to the growth rate of students. Besides, Teachers' professional quality remains improving, and their enthusiasm for teaching is low. The construction level of whole teaching team remains improving.

b). Classroom subject is unclear. In current college English classroom teaching, teachers mainly adopt cramming teaching mode due to the influence of traditional teaching idea, but ignore the requirements of regarding students as the subject in course reform. The teachers who should play a guiding role become the subject in teaching, while students are in the negative acceptance status.

c). Teaching mode and method fall behind. In current college English classroom teaching, teachers can neither effectively apply modern information means in teaching activity not adapt to the 
development requirement of teaching activity due to the reason of ideology. Teaching mode and method are single and fall behind. For many years, teachers teach in classroom in college English classroom teaching, and students passively accept. Besides, big class system is adopted. Teachers infuse knowledge to students, and students take notes and do exercises. In terms of teaching means, traditional blackboard writing and teachers' explanation are the main methods. Teachers are unable to effectively apply modern information means and multimedia technology. Moreover, most colleges lack superior teaching software.

\section{Students' individuation differences are obvious and teachers cannot teach them according to their individualities}

The college scale and enrollment scale have expanded continuously in recent years, so students' differences expand continuously. Significant differences appear in the aspect of learning ability. However, teachers can neither teach students according to their individualities nor carry out differential teaching. They carry out inform teaching for all students, so teaching effect is not obvious. The students with solid foundation feel too easy, while the students with poor foundation feel too difficult and cannot learn knowledge. Such uniform teaching makes students lack learning interest and fail to form good learning habits.

\section{Examination method is too single and rigid , and supervision mechanism is not perfect enough}

CET-4 and CET-6 has fixedly become a standard to measure students' performance and quality of college English teaching. The examinations contents and question types refer to foreign examinations and do not conform to actual requirements. Meanwhile, they do not comply with talent standards Chinese society needs. Thus, CET- 4 and CET-6 cannot accurately measure students' language communication ability and even to some extent brings about negative effect on college English teaching quality.

At present, various colleges mainly take final examination and ordinary test as the main means in assessing students' English performance. But in actual examination process, assessment requirements are lowered due to various factors, and the examination standards are not normative and sound enough. Even requirements are lower again and again in the final examination. Thus, assessment means becomes a mere formality and lacks practical significance. Besides, there is lack of sound and feasible supervision mechanism in the assessment process.

\section{Colleges lack scientific management mode and teaching environment remains improving}

Under long-term inherent thinking model, people do not pay much attention to English course teaching, so there is lack of certain scientificity and rationality in teaching management. Teaching randomness and teaching requirement ambiguity appear. Thus, teaching quality and level lower. Teaching equipment update cannot catch up with teaching requirements. Modern information means such as multimedia technology are not completely applied in teaching. There is lack of modern teaming means and equipment.

\section{Countermeasures for college English classroom teaching}

\section{To establish correct teaching concept}

Correct teaching concept is the guarantee of college English classroom teaching. Obsolete teaching idea and teaching management system will hinder promotion of teaching quality. College education quality is a multi-layer idea, while traditional college teaching idea is a kind of knowledge quality idea and traditional college teaching quality is measured according to the quantity of knowledge students master and their skill level. The talents needed by current society are interdisciplinary talents with application ability and innovation spirit. Thus, students not just need to master solid skills and abilities, but also should learn actively. It is required to change traditional talent training concept in 
college English teaching and establish ability-based teaching concept which combines knowledge and quality. Meanwhile, teachers should pay attention to cultivating students' language application ability and apply the knowledge in actual teaching situation ${ }^{[4]}$.

\section{To lay emphasis on cultivating students’ language application ability}

In current teaching process, it is required to adapt to social demand, cultivate applied talents, and abandon traditional teaching concept. Teachers should combine actual conditions to create teaching situation in teaching activity, focus on students' communication ability, make students exchange in English in actual life, guide them overall apply the knowledge and comprehensively improve their language application ability. In this way, applied interdisciplinary talents who meet social demand can be cultivated, and thus college English classroom teaching quality may improve.

\section{To improve teachers' professional quality}

Teachers as the guides in modern classroom play an important role in college English classroom teaching. Thus, it is necessary to improve teachers' professional quality and build a teaching team with high professional quality.

a). A high-quality, professional and exploration-based teaching team should be built. Teachers should expand their scope of knowledge and own basic ability to impart knowledge according to college English teaching features. Meanwhile, teachers should own certain scientific research innovation ability, update teaching concept in time and adapt to social development.

b). The status of teachers in classroom teaching should be specified. Under the requirements of new course reform, students are the subject of classroom teaching, and teachers mainly guide students in classroom teaching. Teachers should change traditional teaching mode, interact and exchange with students and make students take active part in classroom teaching and learn actively.

c). To establish lifelong training system for teachers and create new teaching mode and method With rapid update of knowledge, all teachers should establish lifelong learning awareness, including English teachers. Besides, teachers should enhance teaching awareness, improve large class teaching mode, apply modern information means in teaching, change "cramming" teaching mode, actively interact and communicate with students and let students learn actively.

\section{To attach importance to individuation and carry out teaching according to students' aptitude}

Different from other disciplines, English classroom teaching as an applied language discipline should be student-centered and makes students improve English level through long-term subtle influence. Teachers should create corresponding language learning situation, fully mobilize students' learning initiative, carry out individualized teaching and teach students according to their aptitude

"Teaching students according to their aptitude" has been implemented in teaching process. To really achieve this, teachers should first know students' real situation, combine their situation to stimulate their learning interest, and guide them to think actively. In this process, teachers should establish correct teaching concept so as to really promote college English classroom teaching quality.

\section{Conclusion}

Under current social background and economic globalization, education globalization also becomes an inevitable trend. College English education is faced with severe challenges. Thus, it is required to establish scientific and rational teaching concept, pay attention to training students' language application ability, improve teachers' professional quality, attach importance to individuation and carry out teaching according to students' aptitude so as to facilitate improvement of students' English level, promote progress of college English classroom teaching and cultivate interdisciplinary applied talents for the society. In addition, teachers should take students as the center in teaching, give play to students' active consciousness, really promote improvement of college English classroom teaching quality and exert the function of new teaching concept. 


\section{References}

[1] Hao Tugen, Yan Hongfeng, Analysis of current situaiotn, defects and countermeasures of college English classroom teaching mode. Journal of Anhui Agricultural University (Social Sciences), 2005, 01:127-133.

[2] Tang Lili, Analysis of current situation and countermeasures of college English classroom teaching - classroom teaching questionnaire of Luzhou Vocational and Technical College. New Curriculum Research (II), 2010, 01:181-183.

[3] Fu Han, Current situaiotn and cause of interactive teaching mode for college English classroom. Learning Weekly, 2014, 35:39.

[4] Cai Li, Current situaiotn and countermeasures of college English classroom teaching evaluation. Journal of Jiamusi Vocational Institute, 2015, 07:272-273. 